\title{
Characteristics of cattle breeders and dairy production in the southeastern and northeastern mesoregions of Pará state, Brazil
}

\author{
Características dos pecuaristas e da produção leiteira nas \\ mesorregiões sudeste e nordeste do estado do Pará, Brasil
}

\author{
Vanderson Vasconcelos Dantas ${ }^{1 *}$; Ricardo Pedroso Oaigen ${ }^{2}$; \\ Marcos Antônio Souza dos Santos ${ }^{3}$; Bruno Spacek Godoy ; Flávio da Silva ${ }^{5}$; \\ Renato Pinto Corrêa ${ }^{5}$; Felipe Nogueira Domingues ${ }^{6}$; Cristiane Soares Simon Marques ${ }^{7}$
}

\begin{abstract}
The objective of this study was to characterize the dairy production systems of the southeastern and northeastern mesoregions of Pará state. A total of 112 questionnaires were administered on rural properties with dairy cow milk production in the municipalities of Ulianópolis and Irituia from April to May 2013. The activity was conducted mainly by men between 36 and 70 years of age. The education level was low, with $67 \%$ of the cattle breeders having incomplete basic education and $20.5 \%$ being illiterate. Regarding herd feeding, only $19.6 \%$ of the breeders used energy supplements, and $13.39 \%$ used roughage supplements. Sanitation control was performed by $99.1 \%$ of the breeders, with vaccines against foot and mouth disease and brucellosis being the most common vaccines because they are mandatory. Milking was performed manually on $98.2 \%$ of the properties, and pre-dipping and post-dipping techniques were used on only $2.7 \%$ and $3.6 \%$ of the properties, respectively. Regarding management, $84.8 \%$ of the breeders did not perform financial planning, and $99.1 \%$ did not have a defined chart of accounts and cost centres and were unaware of their production costs. Average herd productivity was $4.34 \mathrm{~L} \mathrm{cow}^{-1}$ day $^{-1}$, with average production varying between $30 \mathrm{~L} \mathrm{day}^{-1}$ in units with fewer than 10 lactating cows and $355 \mathrm{~L}$ day $^{-1}$ in those with over 55 cows. Age and education level were shown to hinder the access to knowledge and technological innovations in products, processes and management.
\end{abstract}

Key words: Amazonia. Cow milk production. Competitiveness. Production systems.

\section{Resumo}

Objetivou-se com este estudo a caracterização dos sistemas de produção de leite das mesorregiões sudeste e nordeste paraense. Foram aplicados 112 questionários em propriedades rurais, que trabalham

\footnotetext{
${ }^{1}$ Discente do Curso de Mestrado em Ciência Animal, Universidade Federal do Pará, UFPA, Belém, PA, Brasil. E-mail: vd_dantas@ hotmail.com

2 Prof. Adjunto, Universidade Federal do Pampa, UNIPAMPA, Uruguaiana, RS, Brasil. E-mail: rpoaigen@gmail.com

${ }^{3}$ Prof. Adjunto, Instituto Socioambiental e dos Recursos Hídricos, Universidade Federal Rural da Amazônia, UFRA, Belém, PA, Brasil. E-mail: marcos.santos@ufra.edu.br

${ }^{4}$ Prof. Adjunto, Universidade Federal do Pará, UFPA, Belém, PA, Brasil. E-mail: bspacek@ufpa.br

${ }^{5}$ Discentes de Graduação em Medicina Veterinária, Universidade Federal do Pará, UFPA, Castanhal, PA, Brasil. E-mail: flavioifpa@gmail.com; renatoveterinario2010@gmail.com

${ }^{6}$ Prof. Adjunto, Faculdade de Medicina Veterinária, Universidade Federal do Pará, UFPA, Castanhal, PA, Brasil. E-mail: felipend@ufpa.br

${ }^{7}$ Discente do Curso de Mestrado em Ciência Animal, Universidade Federal do Pará, UFPA, Belém, PA, Brasil. E-mail: cristianevet2011@bol.com.br

* Author for correspondence
} 
com bovinocultura leiteira nos municípios de Ulianópolis e Irituia, entre os meses de abril e maio de 2013. A atividade era conduzida predominantemente por homens, com idade variando entre 36 a 70 anos. O nível de escolaridade identificado foi baixo, onde $67 \%$ dos pecuaristas possuiam ensino fundamental incompleto e $20,5 \%$ eram analfabetos. Com relação à alimentação do rebanho, apenas $19,6 \%$ realizavam suplementação com concentrado e 13,39\% com volumoso. O controle sanitário era realizado por $99,1 \%$ dos produtores, sendo as vacinas contra febre aftosa e brucelose as mais aplicadas por serem obrigatórias. Em 98,2\% das propriedades a ordenha era realizada de forma manual, sendo que apenas $2,7 \%$ e 3,6\% respectivamente faziam uso das técnicas de pré-dipping, e pós-dipping. Quanto à gestão $84,8 \%$ não realizavam a composição do planejamento financeiro e $99,1 \%$ não possuíam plano de contas e centro de custos definidos, desconhecendo o custo de produção. A produtividade média do rebanho foi de 4,34 (L vaca ${ }^{-1}$ dia $\left.^{-1}\right)$, com produção média variando entre $30 \mathrm{~L} \mathrm{dia}^{-1}$ em unidades com menos de 10 vacas em lactação e 355 litros naquelas com mais de 55 vacas. Verificou-se que variáveis idade e escolaridade compromete o acesso ao conhecimento e as inovações tecnológicas de produtos, processos e gestão.

Palavras-chave: Amazônia. Bovinocultura leiteira. Competitividade. Sistemas de produção.

\section{Introduction}

Pará state is the $11^{\text {th }}$ largest producer of dairy products in Brazil. Regionally, Pará is the second largest producer, accounting for $28.47 \%$ of the dairy production in northern Brazil, following only Rondônia state, which is the ninth largest dairy producer in the country (IBGE, 2014).

Dairy production plays an important role in the regional economy because of the human resources involved in this activity, its income generation and its compatibility with family farming. Notwithstanding its importance, it still faces a number of problems in this region, such as the small degree of herd specialization for dairy production, resulting in low productivity per cow and per area unit (SENA et al., 2013).

Although dairy production is still being performed by unspecialized breeders with limited technology use and seasonal variation, it has increased in Pará, with an annual growth rate of $3.55 \%$ between 1990 and 2014, increasing from $231.497 \mathrm{~L}$ in 1990 to 554.195 L in 2014 (IBGE, 2014).

Dairy production is concentrated in the southern region of this state, with the southeastern and southwestern mesoregions contributing $81.16 \%$ of the production in 2014. The southeastern mesoregion stands out in terms of the number of dairy-producing properties and the estimated total production, which corresponds to approximately $70.95 \%$ of the milk produced in this state. Its land ownership structure consists of large land properties and a large number of settlements with family-based production. The family structure is attributable to the settlements of the National Institute of Colonization and Agrarian Reform (INCRA) and colonization in the 1970s and 1980s (MDA, 2006; IBGE, 2014).

The dairy production in northeastern Pará has been showing signs of stagnation. In 2014, this area was responsible for only $4.74 \%$ of the state's dairy production $(26.291 \mathrm{~L})$, making it the fourth most productive region in the state (IBGE, 2014). Dairy production in this region has become less attractive because of agricultural alternatives (fruit production, black pepper and other perennial crops), which constitute the main economic activity in this region (REBELLO et al., 2011).

Understanding and characterizing the drivers of the competitiveness of dairy production in Brazil is essential for establishing strategies that are compatible with the local realities of the production systems. Knowledge of the rural properties and the factors that affect their performance should support the development and transfer of technologies suitable for the agents involved in the production chain. Among these factors are the producer's profile, the production system, the 
activity management, the product's quality and other external factors (environment and market).

Thus, the present study aimed to characterize dairy production in the southeastern and northeastern mesoregions of Pará state to generate information to benefit the dairy cattle sector in Pará state.

\section{Materials and Methods}

This study was conducted in the municipalities of Ulianópolis and Irituia, which are located in the southeastern and northeastern mesoregions of Pará state, respectively, through administering questionnaires at 112 properties engaged in dairy cattle production from April to May 2013.

Given that the present study addresses complex production systems, as is the case for all zootechnical activities, the questionnaires were formulated by an interdisciplinary team of professors from the Federal University of Pará who are specialists in agricultural and social sciences. The questionnaires were composed of four parts, which we call drivers: the production system and the producers social and economic profiles; the hygiene and sanitary conditions of milking; the activity management; and the external environment. The four drivers contained 50, 25, 30 and 25 questions, respectively. The producers answers were used to assess the importance of each driver within the system by observing the main factors affecting performance and, therefore, competitiveness.

The questionnaires were applied by UFPA graduate and undergraduate students, all of whom received preliminary training. To collect the information in a uniform manner and ensure that variation in the responses resulted from individual differences and not the way the responders were addressed by the researchers, all interviews followed a previously structured script.

The study sample size was determined from a secondary data survey performed by the Municipal
Secretariats of Agriculture, the Technical Assistance and Rural Extension Corporation (Empresa de Assistência Técnica e Extensão Rural - EMATER) and the Agricultural Defence Agency of Pará State (Agência de Defesa Agropecuária do Estado do Pará - ADEPARÁ) to obtain information on dairy producers in each municipality. The sample size was defined according to Equation 1 (MARTINS, 2005).

$$
n=\frac{Z^{2} \cdot(p) \cdot(q) \cdot N}{(N-1) \cdot e^{2}+Z^{2} \cdot(p) \cdot(q)}
$$

where, $n$ is the calculated sample size, $N$ is the number of producers, $Z$ is the confidence level, $e$ is the sampling error, $p$ is the rate of occurrence of the phenomenon and $q$ is the complimentary percentage, calculated as (100 - p). A confidence interval of $95 \%$, sampling error of $5 \%$ and rate of occurrence of the phenomenon of $80 \%$ were adopted.

The total sample size was 110; however, considering the availability of properties, this number was increased to 112, with 55 in Ulianópolis and 57 in Irituia. After determining the sample size, an itinerary of visits to the properties was defined according to the location of each property to administer the questionnaire to the landowner or the person responsible for the production system.

Considering the structure of the research, the present study may be characterized as a combination of qualitative and quantitative research, which, according to Neves (1996), allows better understanding of the phenomenon being studied.

The statistical treatment of the data was performed using Microsoft Excel 2010 and the statistical software SPSS, version 18.0, and graphical analysis of the percent frequency distribution was conducted. This method aims to group the data by occurrence classes, summarizing the analysis of a data set in plots and tables (MARTINS, 2005). 


\section{Results and Discussion}

\section{Producers' characteristics}

The results showed that the dairy activities are managed mostly by men (approximately 94.6\%) and that, although dairy production also employs women, their participation does not suggest that they are responsible for managing the properties. Among all tasks, women appear to be primarily responsible for farms' internal tasks, whereas men are responsible for internal tasks and external tasks related to business management, product sales and input purchases.

Magalhães (2009) states that, with the development of dairy production and markets and the consequent increase in this activity's economic importance, men began to dominate this activity. Additionally, the way in which the organizations underwent modernization further increased masculine dominance in family production. The present study showed that, although women participate in dairy production, men engage in classes and training activities relating to the management and professionalization of dairy production.

Regarding age, the present study showed that $49.10 \%$ of the producers are 36 to 50 years old and that $41.07 \%$ are over 50 years of age (Figure 1). The average age is 49 years, indicating that this activity is conducted by relatively old producers. Indeed, young people may have little interest in this, considering it tiring and receiving no vacation, no leisure time on the weekends and low income.

Figure 1. Ages of the dairy producers interviewed in the southeastern and northeastern mesoregions of Pará state.

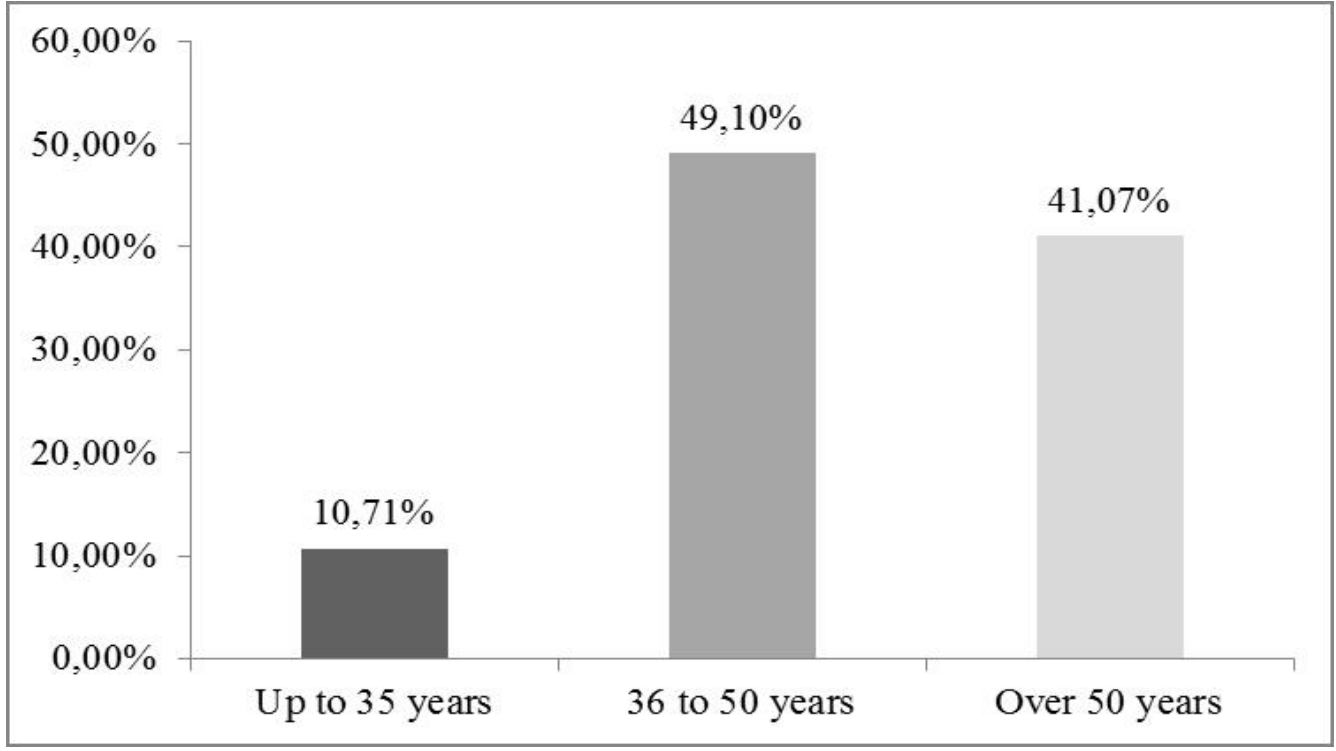

\section{Education level}

Regarding the education level, most producers have not completed basic education (Figure 2). Considering that the producers' average age is 49 years, it seems apparent that the producers' education level will be unlikely to change unless specific public policies are enacted. Analysing the socioeconomic profile of dairy production in settlements in the semiarid region of Sergipe state, Oliveira et al. (2013) found that people with lower education levels experience more difficulties in accepting new technologies and assimilating information related to management practices. Therefore, age and education level are 
likely related to producers' access to knowledge transformations in the dairy agroindustrial and their likelihood of adapting to technological system.

Figure 2. Education levels of the dairy producers in the southeastern and northeastern mesoregions of Pará state.

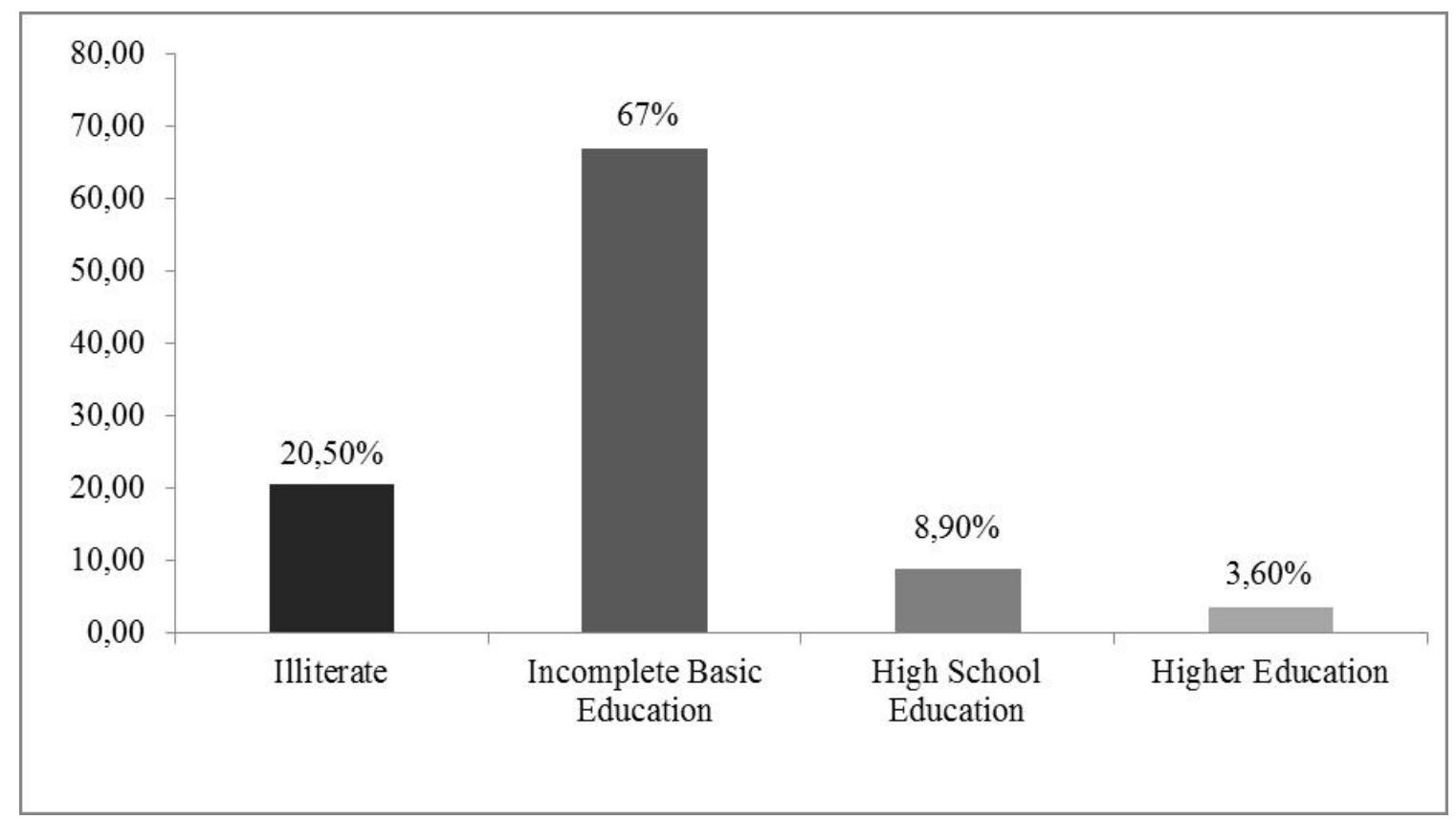

\section{Housing and electricity}

In total, $71.4 \%$ of the producers live on rural properties, and $28.6 \%$ live in urban areas. The fact that most producers reside on the properties is positive because it allows greater involvement in the management and control of the activities. Characterizing the dairy production systems in the irrigated perimeter of Petrolina, Pernambuco state, Neves et al. (2011) noted that $53.6 \%$ of the producers lived in rural establishments and that the remaining $46.4 \%$ lived in urban zones, which was justified by the relatively short distance between the properties and the city.

Regarding electricity, $13.4 \%$ of the properties do not have this service. According to Cruz et al. (2004), rural electrification is important for human, economic and social development because it allows greater comfort, satisfaction, access to communication and information and the mechanization of production for increased productivity. The lack of electrification at these properties limits their development because the producers have no method of storing milk; have limited access to water, which must be obtained in buckets from wells; and cannot use machinery to chop and ensilage forage, instead using machetes to chop the sugarcane used for forage, even though they have other equipment. In addition, production diversification with dairy derivatives is not possible. Thus, specific actions by public administrators are needed to supply electricity and promote social, productive and economic development among these producers.

\section{Length of time in dairy activities}

Most producers (46.6\%) have been engaged in this activity for 1 to 5 years. The production systems 
characterized by producers with little management experience exhibit low performance. In contrast, the length of experience in the activity correlates with the acquisition of knowledge on dairy production systems (ALEIXO et al., 2007). Thus, producers with more experience in the activity produced increased amounts of milk, with possible increases in productivity and, therefore, profitability.

According to García et al. (2012), the lack of producer experience in cattle management is one of the factors leading to the abandonment of the activity because most relevant knowledge comes from practice. In addition, in the Amazon region, dairy cattle breeding developed only recently as part of the region's colonization process, especially since the 1990s and through the growth of family agriculture in the region; this fact also contributed to producers' limited experience in performing this activity (CARVALHO et al., 2012). This is unlike other Brazilian regions, such as the south and southeast, which according to Fernandes et al. (2004), have greater knowledge and traditions of cattle breeding for both meat and dairy.

\section{Production characteristics}

Dairy production in this region is extensive, with pastures as the main food source for the herds.
Gonçalves and Teixeira Neto (2002) characterized the production system in southeastern Pará and noted that $94 \%$ of the producers perform activities of this type (extensive). The potential for pasturebased dairy production systems in Brazil is evident, especially in the northern region; however, the viability of this system depends on appropriate forage selection and factors such as intensive pasture use involving mechanization, soil correction and appropriate management (DIAS-FILHO, 2011). The rational use of pasture, as in semi-intensive systems, permits balancing high production and the forage's nutritional value, facilitating the uniform use of pastures and, thus, higher dairy production (GONÇALVES et al., 2005).

The total area ranged from 7 to 1,600 ha, with most properties consisting of 50 to 100 ha, with an average production of $90.16 \mathrm{~L}$ per day (Table 1). Dairy production is the main activity for $84.8 \%$ of the research subjects, but $86.6 \%$ are also engaged in other production activities. The average cattle herd size in the rural establishments is 46 animals, and the landowners were classified according to the effective number of dairy cattle. The smallest producers had fewer than 10 cows and corresponded to $5.35 \%$ of the interviewees, whereas the largest ones $(23.21 \%)$ had over 50 animals and, on average, 20 lactating animals (Table 2).

Table 1. Dairy properties' characteristics, including their size in ha, dairy cow herds during the year, daily production and productivity, in the southeastern and northeastern mesoregions of Pará state.

\begin{tabular}{lcccc}
\hline \multicolumn{1}{c}{ Property size class } & $\begin{array}{c}\text { Percent of } \\
\text { properties }\end{array}$ & $\begin{array}{c}\text { Average cow herd of } \\
\text { the property/year }\end{array}$ & $\begin{array}{c}\text { Average dairy } \\
\text { production per day }\end{array}$ & $\begin{array}{c}\text { Productivity } \\
\text { L }_{\text {cow }} \text { day }^{-1}\end{array}$ \\
\hline Under 50 ha & 22.3 & 19.16 & 39.26 & 4.47 \\
50 to under 100 ha & 35.7 & 39.57 & 90.16 & 4.51 \\
100 to under 200 ha & 19.5 & 58.32 & 97.79 & 3.99 \\
200 to under 400 ha & 17 & 78.21 & 129.15 & 4.06 \\
Over 400 ha & 5.4 & 48.83 & 109.41 & 4.78 \\
\hline
\end{tabular}


Table 2. Classification of the dairy producers based on the number of animals, number of lactating animals and average dairy production in the southeastern and northeastern mesoregions of Pará state.

\begin{tabular}{lcccc}
\hline $\begin{array}{c}\text { Animals on the } \\
\text { property }\end{array}$ & $\begin{array}{c}\text { Average number of } \\
\text { lactating animals }\end{array}$ & $\begin{array}{c}\text { Number of } \\
\text { properties }\end{array}$ & $\begin{array}{c}\text { Average daily dairy } \\
\text { production (L) }\end{array}$ & $\begin{array}{c}\text { Animal productivity } \\
\text { L cow } \text { day }^{-1}\end{array}$ \\
\hline Fewer than 10 & 6 & $31(28 \%)$ & 29 & 4.63 \\
10 to 20 & 14 & $44(39 \%)$ & 60 & 4.18 \\
21 to 50 & 29 & $30(27 \%)$ & 127 & 4.15 \\
More than 50 & 70 & $7(6 \%)$ & 355 & 4.78 \\
\hline
\end{tabular}

The average herd productivity was $4.34 \mathrm{~L}$ cow $^{-1}$ day $^{-1}$, which is very low compared to more technological systems and other Brazilian regions, as shown by Lopes et al. (2007); in that study, the cost and scale of dairy cattle production in the main Brazilian states were analysed, and average productivities of $9.86 \mathrm{~L} \mathrm{cow}^{-1}$ day $^{-1}$ in Goiás state, 12.32 $\mathrm{L} \mathrm{cow}^{-1}$ day $^{-1}$ in Minas Gerais, $18.91 \mathrm{~L} \mathrm{cow}^{-}$ ${ }^{1}$ day $^{-1}$ in Paraná and $18.77 \mathrm{~L} \mathrm{cow}^{-1}$ day $^{-1}$ in Rio Grande do Sul were recorded. The factors affecting productivity include the low zootechnical indices of the herd; deficiencies in nutritional, reproductive and sanitation management; and low technological level.

\section{Herd feeding}

Regarding herd feeding, the pasture type most used by the producers $(100 \%)$ is palisade grass $(B$. brizantha), although $62.5 \%$ of the producers also use guinea grass (Panicum maximum) and 40.2\% use koronivia grass (Brachiaria humidicola). The preference for palisade grass in these regions is attributable to its good production pattern and nutritional quality, especially during the rainy season, and its high adaptation to the regional climate and soil and high resistance to pasture leafhoppers (BITTENCOURT; VEIGA, 2001).

Regarding food supplementation, less than half of the producers use energy and roughage supplements, and when supplementation is used, it is applied with no specific criteria (Figure 3). Additionally, supplementation is only used in the dry season, with Pennisetum purpureum var. cameron grass and sugarcane (Saccharum officinarum) being the main roughage used. All producers stated that they use mineral supplementation, either as ready-mixed minerals or minerals mixed with salt $(\mathrm{NaCl})$; however, the concentration and management of these supplies are mostly inadequate.

Notwithstanding the importance of supplementation, Martins et al. (2004) reported that good, well-managed pastures reduce the need for supplementation, especially in the rainy season, and may meet the needs of lactating cows, leading to increased production. According to Salman (2007), the basic principle underlying good management is maintaining a balance between the stocking and accumulation rates of the forage mass, i.e., forage supply (quantity and quality). This depends on understanding the components of the pasture ecosystem, including the forage grass (productive potential, growth rate, adaptability), soil (fertility, texture, topography), climate and animal characteristics, such as behaviour and stocking rate. Deresz et al. (2001) assessed the influence of management strategies in elephant grass pastures on the dairy production of Dutch and Zebu dairy cows and found milk productivities of approximately 10.3 to $10.4 \mathrm{~kg} \mathrm{cow}^{-1}$ day $^{-1}$ in a pasture-exclusive regime. 
Figure 3. Food supplementation of the herd with energy, roughage and mineral salts in the southeastern and northeastern mesoregions of Pará state.

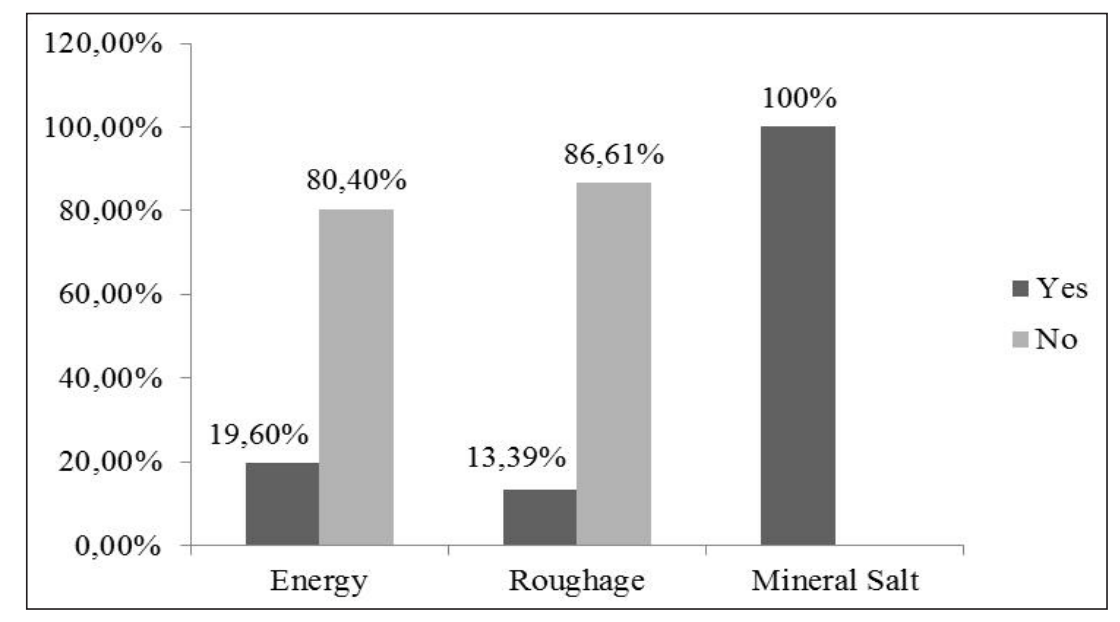

\section{Sanitation management}

Regarding herd sanitation, $97.3 \%$ of the producers stated that they achieve sanitary control by applying vaccines against rabies, botulism and carbuncle. However, the main vaccines are against foot and mouth disease and brucellosis and are mandatory and audited by the ADEPARÁ (Figure 4). When questioned about the treatment of diseases and infections, 98.2\% claimed to employ medication, with diarrhoea, myiasis and mastitis being the most treated diseases. Furthermore, 99.1\% and $97.3 \%$ of the producers claimed to perform the control of endo- and ectoparasites, respectively. As for the diagnostic test for brucellosis and tuberculosis, $71.4 \%$ and $78.6 \%$ of the producers, respectively, did not apply them, increasing the risk of transmitting infectious and zoonotic diseases. As a result, infected herds infect other nearby herds and thereby damage the productive systems, decreasing milk production and calf births (abortions) and causing public health problems (BOLAND et al., 2012; DÍEZ; COELHO, 2013).

Figure 4. Main vaccines applied for the prevention of diseases in dairy-producing properties in the southeastern and northeastern mesoregions of Pará state.

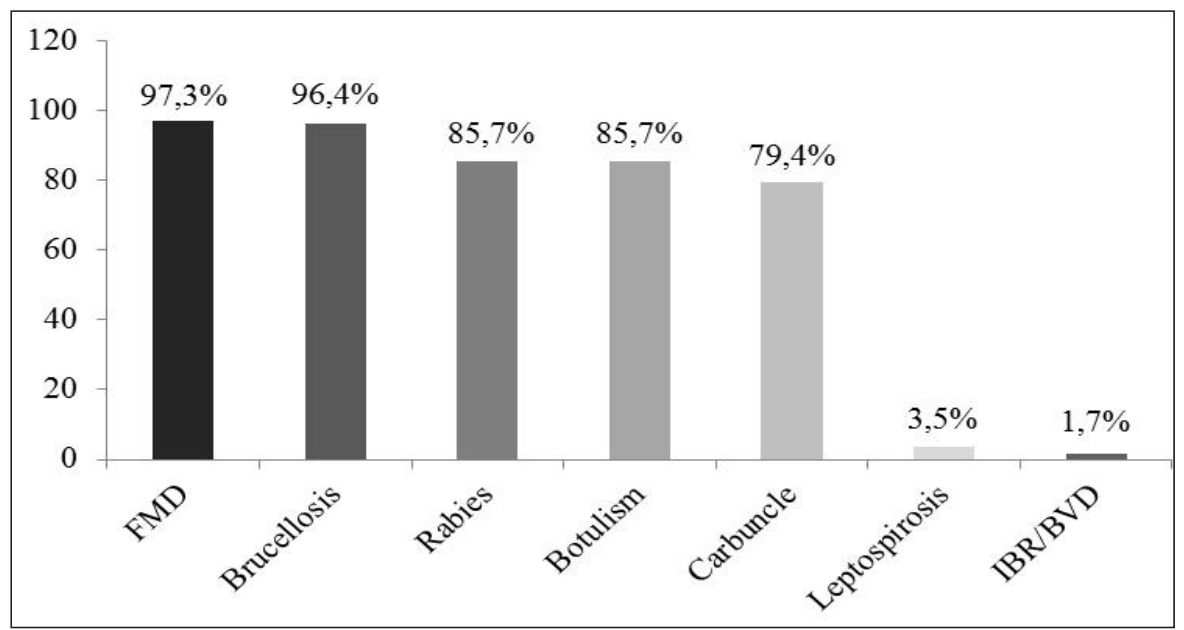

Legend: FMD: Foot and Mouth Disease, IBR/BVD: Infectious Bovine Rhinotracheitis/ Bovine Viral Diarrhea 
Performing a socioeconomic and technical characterization of the dairy activities in Paraná state, Bazotti et al. (2012) observed that few of the interviewed producers performed clinical exams to detect infectious and contagious diseases, with only half conducting brucellosis and tuberculosis tests. These results are similar to those obtained in our study, in which more than half of the producers failed to carry out these exams for disease identification. According to Banai (2002), Waters et al. (2012) and Smith et al. (2013), clinical exams are the most effective way of achieving disease identification, and adequate sanitation management with the application of vaccines may prevent, control and even eradicate some diseases.

\section{Reproductive management}

The techniques used for reproductive management are shown in Figure 5, and most producers use only natural breeding. The low rate of artificial insemination in the herd is notable and represents an extremely negative factor because this technique can accelerate the genetic improvement of the herd, resulting in animals with increased production and reproduction potential (MARQUES, 2005). Evaluating the technological level of dairy producers in western Pará, Sena et al. (2013) observed a low rate of reproductive technologies, highlighting the need for public policies to spread these methods and overcome these deficiencies. This could be achieved by developing courses and training activities for producers by city halls, establishing technical assistance or producer associations, or providing canisters and partial financial subsidizing for semen acquisition.

Figure 5. Reproductive management in the dairy properties of the southeastern and northeastern mesoregions of Pará state (\%).

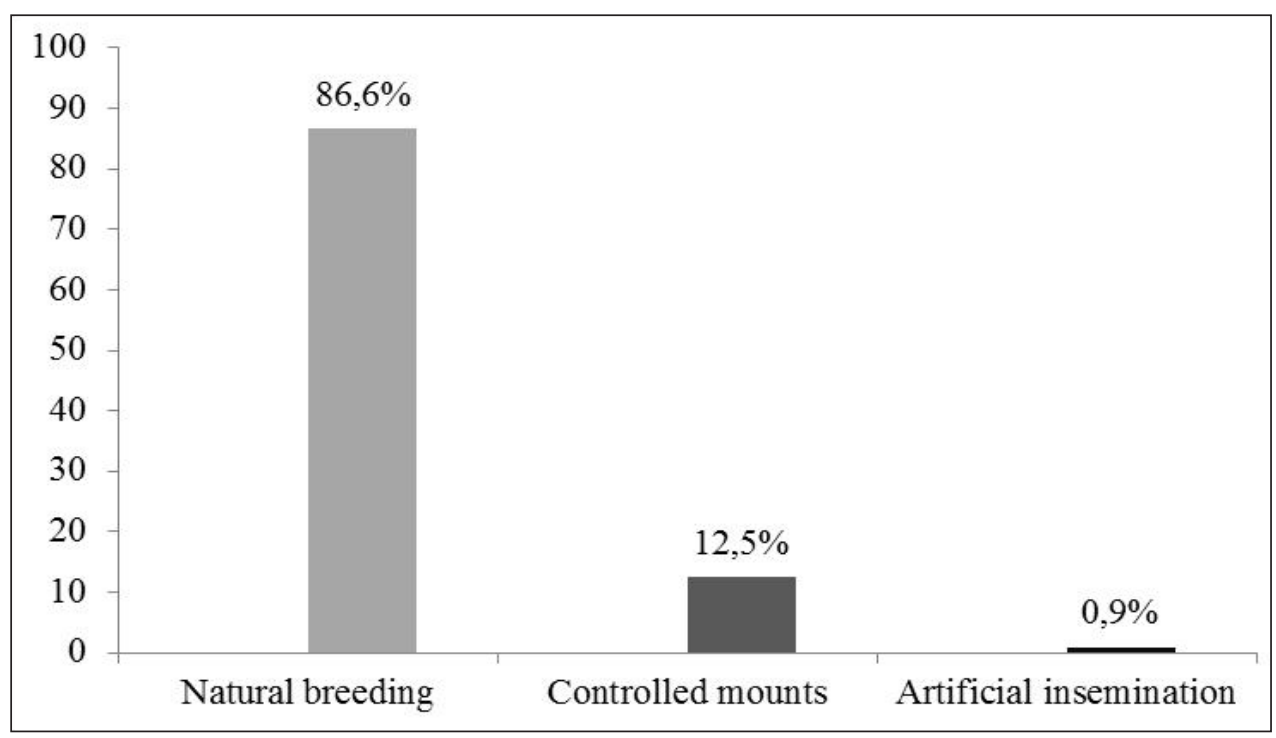

\section{Technical assistance}

Regarding technical assistance, $79.5 \%$ of the producers stated that they do not have access to this service. Furthermore, most of the $20.5 \%$ who said they have access to technical assistance indicate that this assistance is not periodic and, when performed, is provided in the producers' house rather than directly in the production areas. 
According to Oliveira et al. (2013), this lack of technical assistance may be the main factor leading to the low production indices in the herd, hampering producers' access to technological innovations.

Among the producers with access to technical assistance, the main areas of the production system addressed were sanitation management (20.53\%) and nutritional management (15.17\%). Other areas, such as reproductive management and production management, were not addressed. According to Neves et al. (2011), producers consider nutritional and sanitation management to be the most important areas in need of assistance for production development.

Technical assistance may be considered an essential factor for obtaining good results in dairy production activities because its absence precludes the exchange of knowledge and information on dairy production between producers and technicians and reduces the adoption of new, innovationgenerating technological practices. Effective technical assistance is essential for the technical and economic viability of dairy production, especially in small- and medium-sized properties (BAZOTTI et al., 2012).

\section{Milking management and product quality}

Milking was performed manually in $98.2 \%$ of the properties, most of which did not have adequate hygiene conditions, which compromised milk quality. The use of this milking system is related to the high implantation costs of mechanical milking and limitations in access to credit in this region. In addition, the lack of success of some producers in using mechanical milking, and the resulting decrease in production because of the herd's failure to adapt to this system, contributed to a negative opinion about this technique among other producers. Only $19.6 \%$ of the producers wash the cows' teats before milking, and only $12.5 \%$ dry them (Figure 6). Many of the producers $(87.5 \%)$ do not reject the first three milk jets, justifying the fact that the calves nursed for a short time prior to milking; however, 94.6\% stated they discarded the milk with altered colours or lumps, pus or clots. Studying the quality of milk produced in properties with different degrees of specialization, Simioni et al. (2013) reported that milking type and hygiene practices directly affect milk quality.

Regarding post-milking storage, only $3.6 \%$ of the producers use expansion tank, and $0.9 \%$ use refrigerators; the other $95.5 \%$ store milk in tin cans at room temperature with no other type of preservation prior to product delivery, which must occur no more than 2 hours after milking, according to the Normative Instruction 62 of the Ministry of Agriculture Husbandry and Supply (Ministério da Agricultura Pecuária e Abastecimento - MAPA) (BRASIL, 2002). Temperature and storage time directly affect microbial contamination and the quality of the raw milk, and both of these factors are directly related to the multiplication of the microorganisms present in milk and, thus, the total bacterial count (GUERREIRO et al., 2005). To control milk deterioration, the storage temperature must be maintained under $4-5^{\circ} \mathrm{C}$, and therefore, after milking, it is recommended that the milk be cooled as soon as possible to minimize the multiplication of the initial microbiota (SANTOS; FONSECA, 2007). 
Figure 6. Quality-control procedures applied in dairy properties in the southeastern and northeastern mesoregions of Pará state $(\%)$.

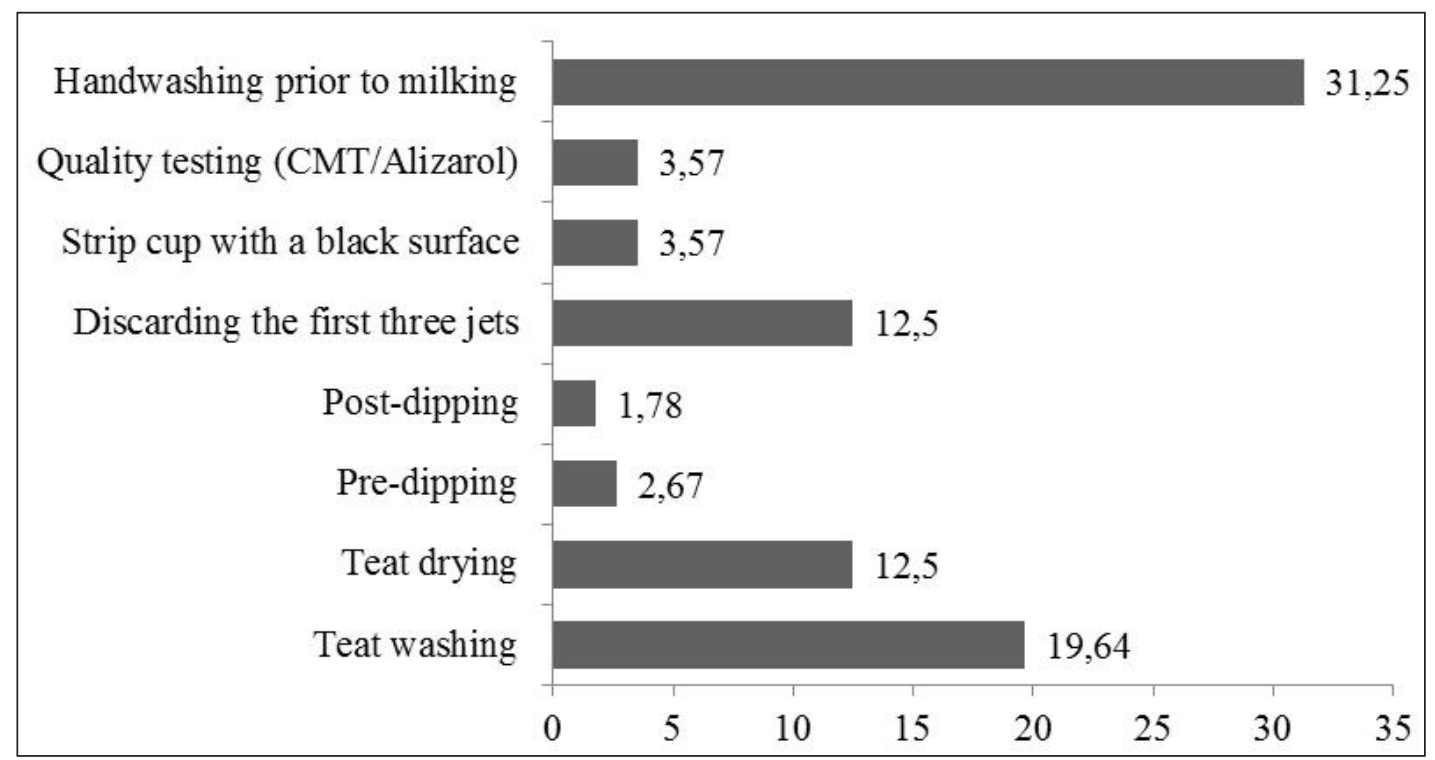

\section{Activity management, planning and organization}

Regarding management, $84.8 \%$ of the producers do not create financial plans or record the property's incomes and expenses. Furthermore, 99.1\% do not have a defined chart of accounts and cost centres; do not calculate profitability indicators, such as operational margin, liquid margin, profitability and balance point; and are unaware of the production costs; only $8 \%$ of the producers stated that they calculate the activity's gross margin.

Regarding herd inventory control, $68.8 \%$ of the producers stated that they perform this procedure only during the mandatory vaccination period and use no defined criteria. Animal identification is employed by $92 \%$ of the producers, but only $8.9 \%$ apply it as a zootechnical management tool. Most producers do not use zootechnical management practices to better manage their properties. Marques et al. (2011) reported that the absence of zootechnical control limits the activity's growth, and management is therefore indispensable to maintain a more stable cash flow and more precisely analyse the costs and their components to increase rural corporations' profitability indices.
Knowledge of production costs based on costgenerating centres permits rural producers to understand the impacts that certain processes and/ or technologies have on their systems, especially regarding the final cost of the product (OAIGEN et al., 2008). However, few rural producers employ economic analysis, and most producers therefore do not know their production costs. Thus, the lack of precise and reliable information leads producers to make wrong decisions based only on their experience and traditions in conducting the business (LOPES et al., 2007).

\section{Activity manpower}

Dairy production in this region is mostly family based, and thus, $53.6 \%$ of producers stated that they do not hire permanent workers. However, $94.6 \%$ said they hire temporary workers in certain periods for specific services, such as cleaning, pasture renovation and fence construction. Among the producers who hire permanent labour, 82.7\% do not sign the workers' papers because doing so is expensive; indeed, the producers must cover taxes, paid vacations and the $13^{\text {th }}$ salary. In addition, the 
payment provided for the services was below the minimum wage. When questioned about workers' qualifications, $33.8 \%$ stated that they pay for courses and training activities, depending on their availability, to obtain better results, whereas $66.2 \%$ said that they do not invest in workers' qualifications because of their high turnover.

Characterizing the dairy production system in the municipality of Paulista-PB, Silva et al. (2010) observed that most workers were family members, with family labour being predominant in the region and landowners primarily living on the properties. This finding explains the small number of hired workers, corroborating the results obtained in our study.

\section{Producer organizations}

Regarding collective organization, $80 \%$ of the producers stated that they do not participate in any association or co-op, and $17 \%$ said they were attached to an association, but when asked whether the members were organized to bargain for better prices when buying and selling products, all responses were negative.

Associations are a manner by which dairy producers may organize themselves to obtain benefits, such as better product prices, the transformation of individual investments into collective investments and specialization in the activity. Collective organizations may help milk producers, supporting producers with small outputs and those who rely on this activity as their sole source of income, aiding them in surpassing the known growth barriers, produce efficiently and sell their products in national markets (KUNZLER; BULGACOV, 2011)

Regarding the producer/supplier relationship, $50 \%$ of the producer stated that they have some fidelity with input supplier corporations. The degree of fidelity regarding dairy products was greater $(83.9 \%)$. When asked whether they received any additional support for production, $93.8 \%$ said that they do not, and only $6.3 \%$ said they are subsidized; $83.3 \%$ of these receive subsidies for quantity, and $16.7 \%$ receive subsidies for quality. Regarding milk marketing, $77.7 \%$ of the production was destined for dairy plants, $21.4 \%$ passed to middlemen and $0.9 \%$ was sold to a co-op. When asked about their knowledge of the price paid for milk at the local, regional and national markets, $97.3 \%$ of the producers answered affirmatively.

\section{Conclusions}

Dairy cattle breeding in the southeastern and northeastern regions of Pará state is characterized by a low technological level. The production capacity exceeds the observed production, but producers must improve their technical and management knowledge to maximize the zootechnical and financial indicators of their rural corporations.

Studies characterizing the production systems are important to understand the properties' reality and may support public and private organizations in developing actions, such as rural extensions, access to credit and compatible technologies, for the agents involved in the productive chain.

\section{References}

ALEIXO, S. S.; SOUZA, J. G.; FERRAUdO, A. S. Técnicas de análise multivariada na determinação de grupos homogêneos de produtores de leite. Revista Brasileira de Zootecnia, Viçosa, MG, v. 36, n. 6, p. 21682175, 2007.

BANAI, M. Control of small ruminant brucellosis by use of brucella melitensis rev. 1 vaccine: laboratory aspects and field. Veterinary Microbiology, Barcelona, v. 90, n. 1-4, p. 497-519, dec. 2002.

BAZOTTI, A.; NAZARENO, L. R.; SUGAMOSTO, M. Caracterização socioeconômica e técnica da atividade leiteira do Paraná. Revista Paranaense de Desenvolvimento, Curitiba, n. 123, p. 213-234, jul./dez. 2012. 
BITTENCOURT, P. C. S.; VEIGA, J. B. da. Avaliação das pastagens de Brachiari brizantha cv. Marandu em propriedades . leiteiras de Uruará, região da Tranzamazônica, Pará, Brasil. Pasturas Tropicales, Cáli, v. 23, n. 2, p. 2-9, 2001.

BOLAND, F.; KELLY, G. E.; GOOD, M.; MORE, S. J. Bovine tuberculosis and udder health in Irish dairy herds. The Veterinary Journal, London, v. 192, n. 1, p. 71-74, 2012.

BRASIL. Instrução Normativa $\mathrm{n}^{0}$ 62: Identidade, qualidade, coleta e transporte do leite tipo A, leite cru refrigerado e leite pasteurizado. Brasília: Ministério da Agricultura Pecuária e Abastecimento - MAPA, 2002. $24 \mathrm{p}$.

CARVALHO, S. A.; TOURRAND, J. F.; POCCARDCHAPUIS, R. Atividade leiteira: um desafio para a consolidação da agricultura familiar na região da transamazônica, no Pará. Cadernos de Ciência e Tecnologia, Brasília, v. 29, n. 1, p. 269-290, jan./abr. 2012.

CRUZ, C. N. P.; MOURAD, A. L.; MORINIGO, M. A.; GODFREY, S. Eletrificação rural: benefícios em diferentes esferas. In: ENCONTRO DE ENERGIA NO MEIO RURAL, 5., 2004, Campinas. Anais... Campinas: NIPE, 2004. p. 1-9.

DERESZ, F.; LOPES, F. C. F.; AROEIRA, L. J. M. Influência de estratégias de manejo em pastagem de capim-elefante na produção de leite de vacas Holandês x Zebu. Arquivo Brasileiro de Medicina Veterinária e Zootecnia, Belo Horizonte, v. 53, n. 4, p. 1-10, ago. 2001.

DIAS-FILHO, M. B. Os desafios da produção animal em pastagens na fronteira agrícola brasileira. Revista Brasileira de Zootecnia, Viçosa, MG, v. 40, p. 270-279, 2011. Suplemento Especial.

DÍEZ, J. G.; COELHO, A. C. An evaluation of cattle farmers' knowledge of bovine brucellosis in northeast Portugal. Journal of Infection and Public Health, Riyadh, v. 6, n. 5, p. 363-369, oct. 2013.

FERNANDES, E. N.; BRESSAN, N.; VERNEQUE, R. S. Zoneamento da pecuária leiteira da região sul do Brasil. Ciência Rural, Santa Maria, v. 34, n. 2, p. 485491, mar./abr. 2004.

GARCÍA, C. G.; DORWARD, P.; REHMAN, T. Farm and socio-economic characteristics of smallholder milk producers and their influence on technology adoption in Central Mexico. Tropical Animal Health and Production, New York, v. 44, n. 6, p. 1199-1211, 2012.
GONÇALVES, C.A.;AZEVEDO, G.P.C.; RODRIGUES FILHO, J. A.; CAMARÃO, A. P. Produção de leite em pastagem de capim-marandu sob dois niveis de concentrado em Terra Alta, PA. Belém: Embrapa Amazônia Oriental, 2005. 32 p. (Embrapa Amazônia Oriental. Boletim de Pesquisa e Desenvolvimento).

GONÇALVES, C. A.; TEIXEIRA NETO, J. F. T. Caracterização do sistema de produção de leito predominante no sudeste paraense. Belém: Embrapa Amazônia Oriental, 2002. 31 p. (Embrapa Amazônia Oriental. Documentos, 142).

GUERREIRO, P. K.; MACHADO, M. R. F.; BRAGA, G. C.; GASPARINO, E.; FRANZENER, A. S. M. Qualidade microbiológica de leite em função de técnicas profiláticas no manejo de produção. Ciência e Agrotecnologia, Lavras, v. 29, n. 1, p. 216-222, jan./fev. 2005.

INSTITUTO BRASILEIRO DE GEOGRAFIA E ESTATÍSTICA - IBGE. Pesquisa Agropecuária Municipal. Rio de Janeiro: IBGE, 2014.

KUNZLER, M. L.; BULGACOV, S. As estratégias competitivas e colaborativas e os resultados individuais e coletivos no associativismo rural em Quatro Pontes (PR). Revista de Administração Pública, Rio de Janeiro, v. 45, n. 5, p. 1363-1393, set./out. 2011.

LOPES, P. F.; REIS, R. P.; YAMAGUCHI, L. C. T. Custos e escala de produção na pecuária leiteira: estudo nos principais estados produtores do Brasil. Revista de Economia e Sociologia Rural, Brasília, v. 45, n. 3, p. 567-590, set. 2007.

MAGALHÃES, R. S. A "masculinização" da produção de leite. Revista de Economia e Sociologia Rural, Piracicaba, v. 47, n. 1, p. 275-300, jan./mar. 2009.

MARQUES, J. R. F. Criação de gado leiteiro na Zona Bragantina. Belém: Embrapa Amazônia Oriental, 2005. 10 p. (Embrapa Amazônia Oriental. Sistema de produção, 2).

MARQUES, P. R.; BARCELLOS, J. O. J.; McMANUS, C.; OAIGEN, R. P.; COLLARES, F. C.; CANOZZI, M. E. A.; LAMPERT, V. N. Competitiveness of beef farming in Rio Grande do Sul State, Brazil. Agricultural Systems, Amsterdam, v. 104, n. 9, p. 689-693, 2011.

MARTINS, C. E.; COSÉR, A. C.; DERESZ, F. Formação e utilização de pastagem manejada em sistemas intensivos de produção de leite. Juiz de Fora: Embrapa Gado de Leite, 2004. 10 p. (Embrapa Gado de Leite. Circular técnica, 79).

MARTINS, G. A. Estatística geral e aplicada. 3. ed. São Paulo: Atlas, 2005. 421 p. 
MINISTÉRIO DO DESENVOLVIMENTO AGRÁRIO - MDA. Plano territorial de desenvolvimento rural sustentável do sudeste do Pará. Brasília: SDT/MDA, 2006. 144 p.

NEVES, A. L. A.; PEREIRA, L. G. R.; SANTOS, R. D. dos; ARAÚJO, G. G. L. de; CARNEIRO, A. V.; MORAES, S. A.; SPANIOL, C. M. O.; ARAGÃO, A. S. L. de. Caracterização dos produtores e dos sistemas de produção de leite no perímetro irrigado de Petrolina/ PE. Revista Brasileira de Saúde e Produção Animal, Salvador, v. 12, n. 1, p. 209-223, jan./mar. 2011.

NEVES, J. L. Pesquisa qualitativa - características, usos e possibilidades. Caderno de Pesquisa em Administração, São Paulo, v. 1, n. 3, p. 1-5, 1996.

OAIGEN, R. P.; BARCELLOS, J. O. J.; CHRISTOFARI, L. F.; BRACCINI NETO, J.; OLIVEIRA, T. E.; PRATES, E. R. Melhoria organizacional na produção de bezerros de corte a partir dos centros de custos. Revista Brasileira de Zootecnia, Viçosa, MG, v. 37, n. 3, p. 580-587, mar. 2008.

OLIVEIRA, A. G. de; OLIVEIRA, V. S. de; SANTOS, G. R. A.; FERREIRA, A. C. D.; SANTOS, G. S.; LIMA, E. P. T. de; SANTOS SOBRINHO, D. C. dos; CARVALHO, C. T. G. Diagnóstico socioeconômico da produção leiteira em três assentamentos de reforma agrária no semiárido do Estado de Sergipe. Semina: Ciências Agrárias, Londrina, v. 34, n. 4, p. 1869-1878, jul./ago. 2013.

REBELLO, F. K.; SANTOS, M. A. S.; HOMMA, A. K. O. Modernização da agricultura nos municípios do nordeste paraense: determinantes e hierarquização no ano de 2006. Revista de Economia e Agronegócio, Viçosa, v. 9, n. 2, p. 209-232, 2011.
SALMAN, A. K. D. Conceito de manejo de pastagem ecológica. Porto Velho: Embrapa Rondônia, 2007. 19 p. (Embrapa Rondônia. Documentos, 121).

SANTOS, M. V.; FONSECA, L. F. L. Estratégia para controle de mastite e melhoria da qualidade do leite. Barueri: Editora Manole LTDA, 2007. 314 p.

SENA, A. L. S.; SANTOS, M. A. S.; SANTOS, J. C.; HOMMA, A. K. O. Avaliação do nível tecnológico dos produtores de leite na região oeste do estado do Pará. Revista de Economia e Agronegócio, Viçosa, MG, v. 10, n. 3, p. 397-418, 2013.

SILVA, R. A.; FERNANDES FILHO, S.; OLIVEIRA, A. V. B.; ARAÚJO, A. S.; SILVA, F. O.; PEREIRA, E. M. Caracterização do sistema de produção de leite do município de Paulista - PB. Agropecuária Científica no Semiárido, Campina Grande, v. 6, n. 2, p. 31-46, abr./ jun. 2010.

SIMIONI, F. J.; BARETTA, C. R. D. M.; STEFANI, L. M.; LOPES, L. S.; TIZZIANI, T. Qualidade do leite proveniente de propriedades com diferentes níveis de especialização. Semina: Ciências Agrárias, Londrina, v. 34, n. 4, p. 1901-1912, jul./ago. 2013.

SMITH, R. L.; TAUER, L. W.; SCHUKKEN, Y. H.; LU, Z.; GROHN, Y. T. Minimization of bovine tuberculosis control costs in US dairy herds. Preventive Veterinary Medicine, Colorado, v. 112, n. 3-4, p. 266-275, 2013.

WATERS, W. R.; PALMER, M. V.; BUDDLE, B. M.; VORDERMEIER, H. M. Bovine tuberculosis vaccine research: historical perspectives and recent advances. Vaccine, Kidlinton, v. 30, n. 2, p. 2611-2622, 2012. 